American University Washington College of Law

Digital Commons @ American University Washington College of

Law

Joint PIJIP/TLS Research Paper Series

$9-2010$

\title{
ACTA and the Specter of Graduated Response
}

Annemarie Bridy

University of Idaho College of Law, abridy@uidaho.edu

Follow this and additional works at: https://digitalcommons.wcl.american.edu/research

Part of the Intellectual Property Law Commons, and the International Trade Law Commons

\section{Recommended Citation}

Bridy, Annemarie. 2010. ACTA and the Specter of Graduated Response. PIJIP Research Paper no. 2. American University Washington College of Law, Washington, DC.

This Article is brought to you for free and open access by the Program on Information Justice and Intellectual Property and Technology, Law, \& Security Program at Digital Commons @ American University Washington College of Law. It has been accepted for inclusion in Joint PIJIP/TLS Research Paper Series by an authorized administrator of Digital Commons @ American University Washington College of Law. For more information, please contact DCRepository@wcl.american.edu. 


\title{
ACTA AND THE SPECTER OF GRADUATED RESPONSE
}

\author{
Annemarie Bridy ${ }^{1}$
}

\begin{abstract}
This article considers the evolution of ACTA's "digital environment" provisions in the context of concerns raised early in the negotiations that the agreement would require signatories to mandate graduated response regimes for online copyright enforcement (à la France's controversial HADOPI system). The Consolidated Text of ACTA released in October 2010, following the final round of negotiations in Japan, contains no provision mandating the adoption of graduated response. Such regimes are tacitly endorsed in the agreement, however, through language in the preamble and the digital environment provisions concerning the promotion of greater cooperation between rights owners and service providers. Moreover, opponents of graduated response should be wary of the fact that public law mechanisms - be they domestic or international-are not the only means by which graduated response can effectively become the law for Internet users. The United States and Ireland provide examples of the trend toward private ordering in the project of online copyright enforcement.
\end{abstract}

\footnotetext{
${ }^{1}$ Associate Professor of Law, University of Idaho College of Law. The author would like to thank Michael Geist, David Post, and Peter Yu for their helpful comments and suggestions. The author would also like to thank Sean Flynn and the Program in Information Justice and Intellectual Property at American University for precipitating a very necessary public discussion on the public interest implications of ACTA.
} 
ABSTRACT ...............................................................................................

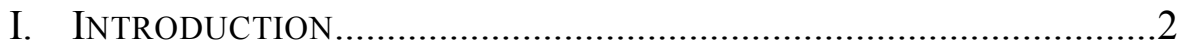

II. The (APPARENT) RetreAt From GRAdUATED ReSPONSE ........... 3

III. The (Actual) Persistence of Graduated Response .............8

A. $\quad$ Privately Ordered Graduated Response in the U.S. ............11

B. $\quad$ Privately Ordered Graduated Response in Ireland ..............13

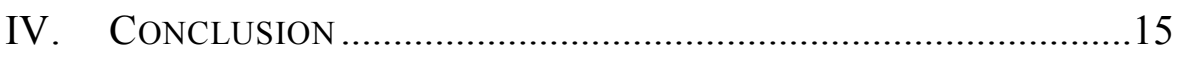

\section{INTRODUCTION}

Much of the controversy surrounding the secret negotiation of the proposed Anti-Counterfeiting Trade Agreement (ACTA) has centered on the possibility that the agreement will require signatories to adopt an online copyright enforcement regime that requires Internet service providers (ISPs) to terminate Internet access for accused repeat copyright infringers. This regime, called "graduated response" or "three strikes," is at the forefront of an international lobbying campaign being waged by corporate copyright owners and the trade organizations that represent their interests to governments throughout the world. Groups like the International Federation for the Phonographic Industry (IFPI) and the International Intellectual Property Alliance (IIPA) have been especially aggressive in pressuring individual governments to require ISPs to take an active role in policing copyrights online by implementing graduated response protocols. Several countries, including the UK, France, South Korea, and Taiwan, have already incorporated graduated response into their domestic copyright enforcement systems. ${ }^{2}$ Similar legislation is on its way to becoming the law

\footnotetext{
${ }^{2}$ See Jeremy de Beer and Christopher D. Clemmer, Global Trends in Online Copyright Enforcement: A Non-Neutral Role for Network Intermediaries?, 49 JURIMETRICS J. 375 (2009) (discussing graduated response in France, South Korea, and Taiwan). The mandate in the UK is set forth in the Digital Economy Bill, which became law in April 2010. See Digital Economy Act, 2010, c. 24. The Act provides that technical measures, including protocols for temporary Internet disconnection, may be phased in by the Secretary of State if a notice regime set forth in the legislation proves inadequate to reduce the level of online infringement. See Digital Economy Act, Explanatory Notes, Commentary on Sections, Topic 2: Online Infringement of Copyright, available at http://legislation.data.gov.uk/ukpga/2010/24/notes/division/5/2/data.pdf, at 1, ๆศ 33-34.
} 
in New Zealand, ${ }^{3}$ although EU countries including Germany and Spain have notably demurred. ${ }^{4}$

Graduated response mandates in the countries that have enacted them do not derive from existing international treaty obligations, and it is all but certain, based on the draft text released following the eleventh and final round of negotiations in Japan, that such mandates will not be included in ACTA. This is, of course, good news for consumer advocates, who legitimately worry that three strikes protocols put too much power in the hands of corporate copyright owners and, among other shortcomings, fail to accommodate fair use/fair dealing exceptions that are built-in to most domestic copyright regimes. The omission of mandatory graduated response from the text of ACTA should not, however, be taken as a sign that the entertainment industries have failed in their concerted effort to globalize graduated response. On the contrary, the draft of ACTA released following the Japan round both accommodates existing graduated response mandates and requires signatories to promote the development of voluntary graduated response regimes in countries where mandates do not exist.

\section{THE (APPARENT) RETREAT FROM GRADUATED RESPONSE}

On April 16, 2010, at the conclusion of the eighth round of ACTA negotiations in New Zealand, the United States Trade Representative (USTR) announced publicly that "no participant is proposing to require governments to mandate a 'graduated response' or 'three strikes' approach to copyright infringement on the Internet." The official draft text of ACTA

\footnotetext{
${ }^{3}$ New Zealand's graduated response mandate is set forth in the Copyright (Infringing File Sharing) Amendment Bill, 119-1 (2010), the text of which may be accessed online via the New Zealand government's web site. See New Zealand Legislation: Bills, http://www.legislation.govt.nz/bill/government/2010/0119/latest/DLM2764312.html. As it was in France, the path to mandatory graduated response in New Zealand is proving to be a rocky one. See, e.g., Pat Pilcher, So Long Section 92A - New Copyright Bill Revealed, Feb. 24, 2010, NZHERALD.CO.UK (describing the controversy surrounding the implementation of graduated response in New Zealand, including the repeal of Section 92A of the Copyright Act, and the introduction of more user-friendly legislation in the form of the Copyright (Infringing File Sharing) Amendment Bill).

${ }^{4}$ See Jacqui Cheng, Germany Says "Nein" To Three-Strikes Infringement Plan, ARS TECHNICA (Feb. 6, 2009), http://arstechnica.com/tech-policy/news/2009/02/germanywalks-away-from-three-strikes-internet-policy.ars; Howell Llewellyn, 'Three-Strikes' Off Anti-Piracy Agenda In Spain, BILlBOARD.BIZ (June 22, 2009), http://www.billboard.biz/bbbiz/content_display/industry/e3i8071e0d9c25cb6b876d3771fb7 e3d102.

${ }^{5}$ Press Release, Office of the U.S. Trade Representative, The Office of the U.S. Trade Representative Releases Statement of ACTA Negotiating Partners on Recent ACTA
} 
released on April 21, 2010 ("the April draft") confirmed that mandatory graduated response was no longer on the table for the negotiating parties. What remained, however, was a more general provision that conditioned ISP eligibility for safe harbor from claims of third party infringement on "an online service provider's adopting and reasonably implementing a policy to address unauthorized storage or transmission of materials protected by copyright."6 Such a policy presumably might, though it needn't necessarily, entail graduated response.

Readers of the April draft who are familiar with U.S. copyright law immediately recognized that the language of the proposed safe harbor provision, which was drafted by U.S. negotiators, was strongly evocative of section 512(i) of the Digital Millennium Copyright Act (DMCA) - the socalled repeat infringer provision. Section 512(i) requires ISPs seeking safe harbor to have "adopted and reasonably implemented . . . a policy that provides for the termination in appropriate circumstances of subscribers and account holders of the service provider's systems or networks who are repeat infringers." 7

The similarity between the April draft of ACTA and the DMCA was even more striking when section 512(i) was juxtaposed with an earlier, leaked draft of the agreement, which contained an explanatory footnote concerning the specific type of policy that would satisfy the requirement: "An example of such a policy is providing for termination in appropriate circumstances of subscriptions [and/or] accounts on the service provider's system or network of repeat infringers." 8 This footnote was conspicuously absent from the April draft, as was any other reference to termination of subscribers or account holders who are "repeat infringers."

Unlike the previously leaked version of ACTA, the April draft retreated entirely from the DMCA's rhetoric of termination of subscribers and account holders - a response, perhaps, to criticism that ACTA's Internet provisions represented little more than an attempt by industry-captured US negotiators to export the DMCA to the rest of the world. Comparing the April draft to section 512 of the DMCA revealed that such criticism was justified. ${ }^{9}$ The April draft extended safe harbor to the same types of

Negotiations, Apr. 16, 2010, http://www.ustr.gov/about-us/press-office/pressreleases/2010/april/office-us-trade-representative-releases-statement-ac.

${ }^{6}$ Anti-Counterfeiting Trade Agreement (ACTA), Consolidated Text Prepared for Public Release, Apr. 2010, at 21.

${ }^{7} 17$ U.S.C. $\S 512(\mathrm{i})$.

${ }^{8}$ Anti-Counterfeiting Trade Agreement (ACTA), Informal Predecisional/Deliberative Draft, Jan. 18, 2010, at 28 n.29.

${ }^{9}$ The similarities do not stop at section 512. In addition to the safe harbor provisions 
providers covered by the DMCA and proposed a notice-and-takedown regime similar in broad outline to the DMCA's. ${ }^{10}$

There were competing proposals in the April draft concerning the appropriate source of a takedown notice: one version required a "legally sufficient notice," which presumably could come from a rights owner, as notices deemed effective under section 512(c) of the DMCA do. ${ }^{11}$ Another version required "receipt of an order from a competent authority," which implies an official, governmental source. ${ }^{12}$ The latter proposal also suggested the necessity for a disinterested adjudication of some kind prior to any enforcement action. No such safeguard is required by the DMCA before content is taken down or, for that matter, before a user's account access is terminated by a provider pursuant to section 512(i). By contrast, a form of due process is required prior to the imposition of access sanctions under the Internet Freedom Provision of the 2009 EU Telecoms Reform. ${ }^{13}$ Due process is also a component of Création et Internet, France's graduated response law, which (as amended) requires judicial review of disconnection decisions that are made initially by HADOPI, the special administrative entity created to implement the graduated response system. ${ }^{14}$

To ensure that statutory enforcement regimes like France's would not be disrupted or pre-empted by ACTA, there was a proposed provision in the April draft_-presented as an alternative to the U.S.-drafted, DMCA-like

for ISPs, ACTA contains provisions that prohibit the circumvention of technological protection measures (i.e, digital rights management or DRM) that control access to and copying of copyrighted works. These provisions bear an unmistakable resemblance to section 1201 of the DMCA.

${ }^{10}$ Compare ACTA Consolidated Text, Apr. 2010, supra note 6, at 19-20 with 17 USC. $\S \S 512(\mathrm{a})-(\mathrm{d})$.

${ }^{11}$ ACTA Consolidated Text, Apr. 2010, supra note 6, at 21; see also 17 USC. $\S \S$ $512(\mathrm{c})(3)(\mathrm{A})$ (defining the elements of an "effective" notification from a rights owner or his/her authorized agent).

${ }^{12}$ ACTA Consolidated Text, Apr. 2010, supra note 6, at 21.

${ }^{13}$ The Internet Freedom Provision, Article 1(3)a of the new Framework Directive, provides that sanctions involving Internet access must be "appropriate, proportionate and necessary within a democratic society, and their implementation shall be subject to adequate procedural safeguards..., including effective judicial protection and due process." Press Release, EU Telecoms Commissioner, EU Telecoms Reform: 12 Reforms to Pave Way for Stronger Consumer Rights, an Open Internet, a Single European Telecoms Market and High-Speed Internet Connections for All Citizens (Nov. 20, 2009). Under Article 1(3)a, Internet users are entitled to a presumption of innocence in proceedings involving accusations of copyright infringement. $I d$.

${ }^{14}$ See Code de la propriété intellectuelle L. 331-21; see also Constitutional Council, Decision $n^{\circ}$ 2009-590 DC (October 22, 2009). The original version of the law, which did not require judicial review, was struck down by France's Constitutional Council. 
notice-and-takedown provision-stipulating that ACTA's safe harbor provisions "shall not affect the possibility of a judicial or administrative authority, in accordance with the Parties [sic] legal system, requiring the service provider to terminate or prevent an infringement."15 The proposed language avoided any reference to disconnection or termination of infringers, although the phrase "terminate or prevent an infringement" could be read to encompass termination of Internet access, pursuant to a governmentally defined protocol, for repeat infringers. ${ }^{16}$

The commonalities between the April draft and the DMCA did not end at the definition of safe harbors for ISPs. The April draft, like the DMCA, provided for the identification of alleged infringers outside the litigation context. ${ }^{17}$ Like the DMCA, the April draft attempted to be responsive to the concerns of ISPs and privacy advocates by expressly excluding a general network monitoring or policing requirement. ${ }^{18}$ In addition, the April draft contained anti-circumvention provisions similar to those found in section 1201 of the DMCA, including section 1201's controversial anti-trafficking provisions, which ban the dissemination of technologies for circumventing technological protection measures employed by rights owners. ${ }^{19}$ With respect to the proposed anti-circumvention provisions, there was a footnote in the April draft indicating a lack of consensus on the issue among negotiators: "At least one delegation has reservations about several elements" of the proposed terms. ${ }^{20}$

The official release of the April draft at the close of the eighth round in New Zealand confirmed for the public at large what was being reported by commentators close to the process: going into the ninth round of negotiations in Luzerne, the provisions of the Internet chapter, even stripped of references to account termination for repeat infringers, remained divisive; consensus on the DMCA-like secondary liability and anti-circumvention

${ }^{15}$ ACTA Consolidated Text, Apr. 2010, supra note 6, at 21.

16 The language of this alternate provision is very similar to language in the EU Directive on Electronic Commerce concerning the availability of injunctive relief against ISPs in cases involving online copyright infringement: "The limitations of liability of intermediary service providers... do not affect the possibility of orders by courts or administrative authorities...requiring the termination or prevention of any infringement...." Directive on Electronic Commerce at $\S 45$.

${ }^{17}$ Compare ACTA Consolidated Text, Apr. 2010, supra note 6, at 21 with 17 U.S.C. $\S$ 512(h).

${ }^{18}$ Compare ACTA Consolidated Text, Apr. 2010, supra note 6, at 21 with 17 U.S.C. $\S$ $512(\mathrm{~m})$.

${ }^{19}$ Compare ACTA Consolidated Text, Apr. 2010, supra note 6, at 22-24 with 17

U.S.C. $\S 1201$.

${ }^{20}$ ACTA Consolidated Text, Apr. 2010, supra note 6, at 23 n.59. 
provisions was proving elusive. ${ }^{21}$ This was true in no small part because the imposition of secondary liability required by provisions in the April draft would represent a change in substantive intellectual property law for

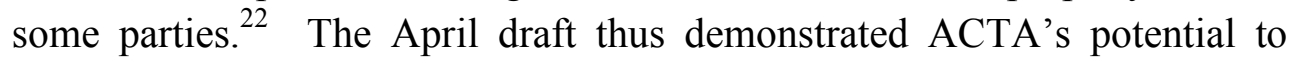
function as a back door for policymaking, through which more expansive substantive rights were being sneaked in under the guise of bettercoordinated enforcement. ${ }^{23}$

Given the persistence of the parties' disagreement over the scope and substance of the Internet provisions, and the USTR's publicly stated goal of concluding the agreement expeditiously, the most controversial elements of the Internet chapter were excised by the end of the tenth round in Washington, DC. At the close of the round, in August 2010, an updated version of the consolidated text was leaked, and the consensus-thwarting secondary liability provisions were gone, along with the safe harbor framework designed to mitigate their impact on ISPs. ${ }^{24}$ A contemporaneous

${ }^{21}$ See, e.g., Posting of Nate Anderson to ARs TECHNICA, ACTA Arrives (Still Bad, But a Tiny Bit Better), Apr. 21, 2010, http://arstechnica.com/tech-policy/news/2010/04/acta-ishere.ars/3 (discussing the international climate for ACTA on the eve of the Luzerne round).

${ }^{22}$ See, e.g., Blog Posting of Michael Geist, Has the US Caved on Secondary Liability in ACTA?, Aug. 26, 2010, http://www.michaelgeist.ca/content/view/5273/125/ ("Secondary liability has proven consistently problematic, however, since many ACTA countries deal with the issue in different ways."); Lynda J. Oswald, International Issues in Secondary Liability for Intellectual Property Rights Infringement, 45 AM. BUS. L.J. 247, 251-252 (2008) ("The considerable diversity in global thought on the issue of secondary liability for intellectual property rights infringement highlights the important fact that not all participants in discussion of this topic start from the same place in terms of legal theory and practice.").

${ }^{23}$ Chapter One of ACTA provides that "[t]his agreement shall be without prejudice to provisions governing the availability, acquisition, scope, and maintenance of intellectual property rights contained in a Party's law." ACTA Consolidated Text, Informal Predecisional/Deliberative Draft, Aug. 2010, at 3. Commentators have pointed out, however, that many of the provisions proposed in the April draft $d o$ affect substantive rights. See Press Release, American University Washington College of Law Program on Intellectual Property and Information Justice (PIJIP), Text of Urgent ACTA Communiqué: International Experts Find that Pending Anti-Counterfeiting Trade Agreement Threatens Public Interests, June 23, 2010, http://www.wcl.american.edu/pijip/go/acta-communique ("What started as a relatively simple proposal to coordinate customs enforcement has transformed into a sweeping and complex new international intellectual property and internet regulation....").

${ }^{24}$ What remained was a general provision requiring that "[e]ach party's enforcement procedures shall provide the means to address the infringement of \{US: copyright or related rights $\}\{\mathrm{EU} / \mathrm{J}$ : intellectual property rights $\}$ in the digital environment, including infringement that occurs via technologies \{US: or services\} that can be used to facilitate widespread infringement." ACTA Consolidated Text, Informal Predecisional/Deliberative Draft, Aug. 25, 2010, at 19. A footnote singled out unlawful file sharing and unlawful 
USTR press release asserting that ACTA "is not intended to include new intellectual property rights or to enlarge...existing intellectual property rights" ${ }^{25}$ hinted at the impetus for the changes.

Not all of the controversial DMCA-like provisions were eliminated by the end of the tenth round, however. Still in the mix going into the eleventh - and final-round of negotiations in Japan were controversial provisions concerning ISP identification of alleged online infringers ${ }^{26}$ and anti-circumvention. $^{27}$ The proposed anti-circumvention provisions continued to include a requirement, backed by the US but opposed by the $\mathrm{EU}$, that violations be actionable even without any nexus to copyright infringement. $^{28}$

By the time negotiations entered the final round, in September 2010, it was apparent to those who had been following the process and comparing successive drafts of the agreement that US aspirations for very aggressive Internet and intermediary liability provisions had been incrementally disappointed. The language of the agreement with respect to the digital environment had evolved, as a result of pressure from both within and outside the formal process, to be more protective of the parties' sovereign prerogatives in areas relating to substantive rights, liabilities, and exceptions. The text of the agreement released officially after the final round ("the October draft") provides further evidence of this trend: it altogether omits the U.S.-backed provision requiring parties to make circumventions actionable per se. ${ }^{29}$

\section{The (ACtuAL) Persistence of GRAduAted Response}

Although the absence of any reference to repeat infringers in the April and October drafts may give the impression that graduated response is not

streaming as examples of such technologies or services. Id. at n.29. Also included in the new provision was a mandate to implement the procedures "in a manner that avoids the creation of barriers to legitimate activity." Id. at 19.

${ }^{25}$ Press Release, Office of the US Trade Representative, Statement of ACTA Negotiating Partners on Recent ACTA Negotiations, Aug. 20, 2010, http://www.ustr.gov/about-us/press-office/press-releases/2010/august.

${ }^{26}$ In the August 2010 leaked text, however, the provision is no longer mandatory. Compare ACTA Consolidated Text, Apr. 2010, supra note 6, at 21 (provision 3 ter.) with ACTA Consolidated Text, Aug. 2010, supra note 24, at 21 (provision 4).

${ }^{27}$ Compare ACTA Consolidated Text, Apr. 2010, supra note 6, at 23 (provision 5) with ACTA Consolidated Text, Aug. 2010, supra note 24, at 21 (provision 7).

${ }^{28}$ ACTA Consolidated Text, Aug. 2010, supra note 24, at 21.

${ }^{29}$ Compare ACTA Consolidated Text, Aug. 2010, supra note 24, at 21 with ACTA Consolidated Text, Informal Predecisional/Deliberative Draft, Oct. 2, 2010, at 16-17. 
part of the enforcement framework contemplated by ACTA, this is only superficially true. The April draft contained an allusive provision requiring signatories to pressure ISPs to cooperate with rights owners:

Each party shall promote the development of mutually supportive relationships between online service providers and rights holders to deal effectively with...copyright and related rights infringement which takes place by means of the Internet, including the encouragement of establishing guidelines for the actions which should be taken. ${ }^{30}$

This mandatory provision remains - albeit in qualified form-in the October draft:

Each party shall endeavor to promote cooperative efforts within the business community to effectively address at least trademark and copyright or related rights infringement while preserving legitimate competition and consistent with each Party's law, preserving fundamental principles such as freedom of expression, fair process, and privacy. ${ }^{31}$

Moreover, in the October draft, for the first time, a statement concerning ISP cooperation with rights owners appears in the agreement's preamble:

The Parties to this Agreement...[d] esiring to promote cooperation between service providers and rights holders with respect to relevant infringement in the digital environment...[a]gree as follows.... ${ }^{32}$

Positioned at the beginning of the agreement, this statement foregrounds the principle on which graduated response is founded: ISPs and rights owners should be collaborating more closely in the project of online copyright enforcement.

The notion that ISPs should be encouraged by government to work with rights holders is reminiscent of the DMCA, which was drafted, according to the statute's legislative history, to "preserve strong incentives for service providers and copyright owners to cooperate to detect and deal with

\footnotetext{
${ }^{30}$ ACTA Consolidated Text, Apr. 2010, supra note 6, at 22.

${ }^{31}$ ACTA Consolidated Text, Oct. 2010, supra note 29, at 15.

${ }^{32}$ Id. at 2.
} 
copyright infringements that take place in the digital networked environment."33 The formalization of such cooperative relationships appears on the IIPA's 2010 global copyright policy wish list: "The copyright industries look to governments to...encourage cooperation by Internet service providers with all content owners, including workable and fair notice and takedown systems and graduated response mechanisms to deal with repeat infringers." 34

Even though ACTA does not mandate graduated response or require disconnection for repeat infringers, and even though the October draft contains no notice and takedown provision, the language requiring governments to take affirmative action to "promote cooperation" between rights owners and ISPs resonates strongly with the industries' demand that ISPs take a more active role in anti-piracy efforts. The industries' international strategy has been to seek government mandates for graduated response where such mandates seem politically achievable and to accept government pressure for graduated response where mandates are too controversial to win legislative approval. This strategy of compelled "voluntary" collaboration comes directly from the playbook of the IFPI, which advocates "government-backed systems of ISP cooperation" and asserts that "government pressure is crucial to producing collective action by all ISPs." 35

Consistent with the IIPA's and the IFPI's rhetoric, rights owners have increasingly come to define "mutually supportive relationships" and "cooperation" between themselves and ISPs in terms of ISPs' willingness to embrace graduated response. This is so much the case that "cooperation" for the copyright industries has come to function as a sort of code word for graduated response. Insofar as the October draft of ACTA requires parties to "endeavor to promote cooperative efforts within the business community," the agreement retains an implicit, sub-textual appeal for global graduated response.

The cooperative relationships that industries seek are now developing in many places through market forces and without government pressure, however, which casts doubt on the need for a provision in ACTA requiring official pressure. A propos of this development, opponents of graduated response should be mindful that public law-be it international or domestic - is not the only vehicle through which graduated response

${ }^{33}$ H. Rep. 105-796, at 72 (1998).

${ }^{34}$ IIPA, Copyright Industries' Global Challenges and Solutions for 2010, http://www.iipa.com/pdf/2010Special301Challenges.pdf.

${ }^{35}$ IFPI, Digital Music Report 2009, http://www.ifpi.org/content/section_resources/dmr2009.html, at 24. 
regimes can be implemented. The United States and Ireland provide instructive examples of how graduated response can effectively become the law for Internet users without ever becoming the law of the land.

\section{A. Privately Ordered Graduated Response in the U.S.}

Whereas the entertainment industry's campaign in Europe and countries abroad has focused on government-mandated graduated response, the campaign in the US has focused on inter-industry negotiations and technology-based solutions capable of private implementation. Believing that the DMCA has failed them as a weapon in the domestic war on piracy, right owners in the U.S. market have set their sights on an enforcement regime that operates on Internet users through a combination of technology and private law mechanisms such as standardized terms of service and acceptable use policies. ${ }^{36}$

There are a number of reasons why U.S.-based ISPs are more receptive now than they were in the past to overtures from rights owners. There is a growing sense among ISPs that there's actually something in it for them if they agree to work more cooperatively with rights owners. For example, Verizon agreed in 2005 to forward notices of infringement to its customers for Disney, in return for which it received the right to transmit Disney programming over its network. ${ }^{37}$ These types of business arrangements are likely to become more common as distribution of non-amateur content over the Internet increases. Music, movies, and TV shows that were once only broadcast are now also streamed, which means that ISPs now mediate the consumption of corporate-produced entertainment in ways they never did before. As a result of the rise of streaming media over broadband, traditional lines of demarcation between corporate producers of content and corporate distributors of content are blurring. The proposed merger between Comcast and NBC Universal is a prime example. If the deal between these two juggernauts survives antitrust scrutiny, it may become the wave of the future, forever transforming the historical relationship between the major corporations that deliver content over the Internet and the major corporations that own the intellectual property rights in that content. When (or if) the corporate distributors of content become its

\footnotetext{
${ }^{36}$ For a full discussion of this shift in enforcement strategy, see Annemarie Bridy, Graduated Response and the Turn to Private Ordering in Online Copyright Enforcement, 89 OR. L. REV. _ (forthcoming 2010).

${ }^{37}$ See Posting of Nate Anderson to ARS TECHNICA, Verizon to Forward RIAA Warning Letters (But That's All), Nov. 13, 2009, http://arstechnica.com/techpolicy/news/2009/11/verizon-to-forward-riaa-warning-letters-but-thats-all.ars.
} 
owners, their stake in the copyright enforcement game will changeradically.

ISPs have also realized the extent to which peer-to-peer (P2P) filesharing traffic, most of which is attributable to copyright infringement, causes congestion on their networks. A key element of the negotiation strategy for rights owners seeking to partner with US broadband providers in the implementation of a network-level solution to online piracy has been the assertion that management of $\mathrm{P} 2 \mathrm{P}$ traffic should be regarded as a matter of mutual concern. The message has not fallen on deaf ears. Comcast's highly controversial use of deep packet inspection technology to throttle BitTorrent traffic in 2007 is one manifestation of the coincidental community of interest that has developed between rights owners and network operators.

Given users' resistance to the idea that that their ISPs will begin functioning actively as the entertainment industry's enforcement agents, ISPs are cagey when it comes to publicizing the nature of their cooperative relationships with major content distributors. To comply with section 512(i) of the DMCA, every major broadband provider in the US includes in its terms of use a provision reserving the right to terminate access for any user who repeatedly infringes copyrights. ${ }^{38}$ Verizon and Comcast expressly reserve the right to do so unilaterally (i.e., in their "sole discretion"). Representatives of major broadband providers including Comcast, Cox, and AT\&T have denied publicly that they are participating in a "three strikes"

\footnotetext{
${ }^{38}$ See, e.g., Comcast Terms of Service, http://www.comcast.net/terms/use/ ("It is Comcast's policy in accordance with the DMCA and other applicable laws to reserve the right to terminate the Service provided to any customer or user who is either found to infringe third party copyright or other intellectual property rights, including repeat infringers, or who Comcast, in its sole discretion, believes is infringing these rights. Comcast may terminate the Service at any time with or without notice for any affected customer or user."); AT\&T Terms of Service, http://my.att.net/csbellsouth/s/s.dll?spage=cg/legal/att.htm\&leg=tos ("AT\&T may, however, immediately terminate or suspend your Member Account and Sub Accounts, and all or a portion of your Service without notice if: ... you...engage in conduct that is a violation of any law, regulation or tariff (including, without limitation, copyright and intellectual property laws"); Verizon Terms of Service, http://www.verizon.net/policies/popups/tos_popup.asp ("In accordance with the Digital Millennium Copyright Act (DMCA) and other applicable laws, it is the policy of Verizon to suspend or terminate, in appropriate circumstances, the Service provided to any subscriber or account holder who is deemed to infringe third party intellectual property rights, including repeat infringers of copyrights. In addition, Verizon expressly reserves the right to suspend, terminate or take other interim action regarding the Service of any Subscriber or account holder if Verizon, in its sole judgment, believes that circumstances relating to an infringement of third party intellectual property rights warrant such action.”).
} 
program in cooperation with the RIAA. ${ }^{39}$ At the same time, however, a Comcast executive disclosed that the company issues between one and two million infringement notices per year to subscribers on behalf of copyright owners. ${ }^{40}$ He also acknowledged that Comcast has suspended the accounts of a small fraction of users in connection with the company's DMCA compliance efforts. ${ }^{41}$ Cox representatives have admitted to having done the same in a small number of cases where repeated notices have gone unheeded by subscribers. ${ }^{42}$

Although the impulse of broadband executives is to deny involvement when they are confronted with questions from the media about "three strikes" and graduated response, ${ }^{43}$ the fact of the matter is that US broadband providers, in the name of DMCA compliance, have been engaged for a number of years in a form of graduated response: They have entered into arrangements with rights owners pursuant to which they forward notices of infringement to subscribers, and at least two major ISPs - Comcast and Cox - are on the record as having suspended access for subscribers who routinely receive and ignore such notices. Such suspensions, which occur without a court order or a judgment of infringement, are permitted under the terms of use to which all subscribers must agree in order to initiate and maintain broadband service. Although it is impossible to gauge with any accuracy to what extent U.S. ISPs are currently cooperating with rights owners in online copyright enforcement, they could be doing so quite extensively without any required disclosure and without running afoul of their existing contractual agreements with their customers.

\section{B. Privately Ordered Graduated Response in Ireland}

Ireland provides another example of privately ordered online copyright

${ }^{39}$ See Chloe Albanesius, Comcast, Others Deny 'Three Strikes" Piracy Plan, PCMAG.COM, Mar. 27, 2009, http://www.pcmag.com/article2/0,2817,2343977,00.asp.

${ }^{40} \mathrm{Id}$.

${ }^{41} I d$.

42 See Sarah McBride, Relationship Status of RIAA and ISPs: It's Complicated, WSJ.COM, Mar. 26, 2009, http://blogs.wsj.com/digits/2009/03/26/relationship-status-ofriaa-and-isps-its-complicated/.

${ }^{43}$ See David Kravets, Top Internet Providers Cool to RIAA 3-Strikes Plan, WIRED, Jan. 5, 2009, http://www.wired.com/threatlevel/2009/01/draft-verizon-o/ ("Two weeks after the Recording Industry Association of America announced it had struck deals with top internet service providers to cut off unrepentant music sharers, not a single major ISP will cop to agreeing to the ambitious scheme, and one top broadband company says it's not on board.”). 
enforcement. Graduated response has become the de facto law for over $40 \%$ of that country's broadband subscribers through a legal settlement between a major ISP_Eircom - and major music and movie distributors (EMI, Sony BMG, Universal, and Warner), which sued Eircom for copyright infringement. After eight days of trial on the merits of the plaintiffs' claims, the parties agreed to a settlement that requires Eircom to implement a graduated response protocol. ${ }^{44}$ The case never went to judgment on its merits.

The "three strikes" protocol adopted by the parties is described in detail in an Irish High Court decision issued in the context of an unsuccessful legal challenge to the settlement. ${ }^{45}$ Upon receiving a first notice of infringement from a computer security firm hired by the plaintiffs, Eircom informs its allegedly infringing customer that $s /$ he has been caught in the act of illegal uploading or downloading. This first warning is included with the customer's monthly bill. Upon receipt of a second notice of infringement by the same customer, Eircom sends a separate letter to the customer that contains a strongly worded warning. The response escalates from the first level to the second level only if fourteen days or more have passed since the first infringement was detected. Upon receipt of a third notice from the computer security firm, Eircom must review all of the evidence against its customer. As with the escalation from the first level of response to the second, fourteen days or more must have passed for the response to graduate to the third level. The first two notices are generated automatically; the third notice, however, triggers a human review. Following human review, a notice of termination is sent to the customer, who is given fourteen days to respond. Eircom considers the response, if any is received, in light of any extenuating circumstances the customer raises. If the customer claims in his or her response that there was a mistake of fact concerning the alleged infringements, Eircom considers that claim as well. If there is no finding in favor of the customer, the customer's Internet service is cut off. No court order is required; the ISP is the sole arbiter of the customer's innocence or guilt.

The legal challenge to the EMI-Eircom settlement involved a claim that the computer security firm's collection of Internet protocol addresses, and its subsequent disclosure of those addresses to Eircom, violated Ireland's Data Protection Acts. After considering each of the arguments raised by the settlement's opponents, the judge concluded that the process is lawful and

\footnotetext{
${ }^{44}$ See EMI Records \& Ors v. Eircom Ltd., [2010] IEHC 108 (Apr. 16, 2010).

${ }^{45}$ See id.
} 
approved implementation of the settlement. ${ }^{46}$ With his decision, graduated response became the law, entirely outside the parliamentary process, for every one of Eircom's 560,000 customers. ${ }^{47}$

\section{CONCLUSION}

At the close of the official negotiations, looking back on the round-byround evolution of ACTA's terms, it seems safe to say that the Internet provisions were among the agreement's most contested and heavily negotiated. References to repeat infringers and account termination were edited out of the agreement well before the final round of negotiations, and with them went the prospect of mandatory graduated response. Related provisions requiring secondary liability for ISPs and a DMCA-like safe harbor framework also fell away, albeit later in the game.

Before breathing a sigh of relief, however, opponents of graduated response should think twice about the possible implications of the provision in the October draft that requires governments to "endeavor to promote cooperative efforts" between rights owners and ISPs. Through this amorphous provision, ISPs could be subject to various forms of governmental pressure to capitulate to copyright owners' demands for privately implemented graduated response regimes. For lawmakers who would rather not place themselves at the center of the controversy over graduated response, private ordering with a government push may prove more palatable than outright government mandates, which prompted very vocal public resistance and dissent in places like France and the UK. Like the negotiation of ACTA itself, officially required private ordering represents a species of policymaking that is insulated from public scrutiny and that can be tailored, by virtue of that insulation, to serve the interests of business at the public's expense.

\footnotetext{
${ }^{46} I d$.

${ }^{47}$ See eircom Web Site, About eircom, http://government.eircom.net/abouteircom.php ("eircom is the leading broadband service provider in Ireland with over 560,000 broadband customers. eircom has a $43 \%$ share of the broadband market.")
} 